\title{
GENERALIZED HERMITE-HADAMARD TYPE INEQUALITIES FOR DIFFERENTIABLE HARMONICALLY-CONVEX AND HARMONICALLY QUASI-CONVEX FUNCTIONS
}

\author{
Muhammad Amer Latif, Sabir Hussain And Yu-Ming Chu*
}

Abstract. Some new Hermite-Hadamard type inequalities for differentiable harmonically-convex and harmonically quasi-convex functions have been discussed, generalizing some existing results in literature. For validity of the results some numerically examples are given.

Mathematics subject classification (2020): 26D15, 26D20, $26 \mathrm{D} 07$.

Keywords and phrases: Hermite-Hadamard's inequality, harmonically-convex function, harmonically quasi-convex function, Hölder's integral inequality.

\section{REFERENCES}

[1] F. X. Chen And S. H. Wu, Some Hermite-Hadamard type inequalities for harmonically s-convex functions, The Scientific World Journal, (2014), Article ID 279158.

[2] F. Chen AND S. Wu, Fejér and Hermite-Hadamard type inequalities for harmonically convex functions, J. Appl. Math., (2014), Article ID 386806, 6.

[3] J. Hadamard, Étude sur les Propriétés des Fonctions Entières en Particulier d'une Fonction Considérée par Riemann, Journal de Mathématique Pures et Appliquées, 58 (1893), 171-215.

[4] Y.-X. Li, M. A. Ali, H. Budak, M. AbBas and Y.-M. Chu, A new generalization of some quantum integral inequalities for quantum differentiable convex functions, Adv. Difference Equ., 2021 (2021), Article 225, 15 pages.

[5] Y.-X. Li, M. H. Alshbool, Y.-P. Lv, I. Khan, M. Riza Khan and A. IssaKhov, Heat and mass transfer in MHD Williamson nanofluid flow over an exponentially porous stretching surface, Case Stud. Therm. Eng., 26 (2021), Article ID 100975, 10 pages.

[6] Y.-X. Li, T. Muhammad, M. Bilal, M. Altaf Khan, A. Ahmadian and B. A. Pansera, Fractional simulation for Darcy-Forchheimer hybrid nanoliquid flow with partial slip over a spinning disk, Alex. Eng. J., 60 (2021), 4787-4796.

[7] Y.-X. Li, A. Rauf, M. Naeem, M. A. Binyamin and A. Aslam, Valency-based topological properties of linear hexagonal chain and hammer-like benzenoid, Complexity, 2021 (2021), Article ID 9939469,16 pages.

[8] Y.-X. Li, F. Shah, M. IJaz Khan, R. Chinram, Y. Elmasry and T.-C. Sun, Dynamics of Cattaneo-Christov double diffusion (CCDD) and arrhenius activation law on mixed convective flow towards a stretched Riga device, Chaos Solitons Fractals, 148 (2021), Article ID 111010, 5 pages.

[9] İ. İsCAN, Hermite-Hadamard type inequalities for harmonically convex functions, Hacettepe Journal of Mathematics and Statistics 43 (6) (2014), 935-942.

[10] M. A. Latif, S. S. DRAGomiR AND E. Momoniat, Fejér type inequalities for harmonically-convex functions with applications, Journal of Applied Analysis and Computation, 7 (3) (2017), 795-813.

[11] M. A. Latif, S. S. Dragomir And E. Momoniat, Some Fejér type inequalities for harmonicallyconvex functions with applications to special means, International Journal of Analysis and Applications, 13 (1) (2017), 1-14.

[12] M. A. Noor, K. I. Noor, M. U. Awana And S. Costache, Some integral inequalities for harmonically h-convex functions, U.P.B Sci. Bull. Serai A., 77 (1) (2015), 5-16. 
[13] M. A. Noor, K. I. Noor, S. IfTIKHAR, Hermite-Hadamard inequalities for strongly harmonic convex functions, J. Inequal. Spec. Funct., 7 (2016), 99-113.

[14] J. PARK, Hermite-Hadamard type inequalities for harmonically quasi-convex functions (II), International Journal of Mathematical Analysis, 8 (33) (2014), 1605-1614.

[15] W. WANG, İ. İsCAN, H. ZHOU, Fractional integral inequalities of Hermite-Hadamard type for $m$-HH convex functions with applications, Advanced Studies in Contemporary Mathematics (Kyungshang), 26 (3) (2016), 501-512.

[16] W. WANG AND J. QI, Some new estimates of Hermite-Hadamard inequalities for harmonically convex functions with applications, International Journal of Analysis and Applications 13 (1) (2017), 15-21.

[17] T.-Y.ZHANG AND FENG QI, Integral inequalities of Hermite-Hadamard type for $m$-AH convex functions, Turkish Journal of Analysis and Number Theory, 3 (2) (2014), 60-64.

[18] T.-Y.ZHANG, A.-P. JI, AND F. QI, Integral inequalities of Hermite-Hadamard type for harmonically quasi-convex functions, Proceedings of the Jangjeon Mathematical Society, Memoirs of the Jangjeon Mathematical Society, 16 (3) (2013), 399-407.

[19] J. E. Pecaric, F. Proschan, Y. L. Tong, Convex functions, partial orderings and statistical applications, Academic, Academic Press, Boston, 1992. 